Sandholtz, Wayne and Alec Stone Sweet (2004). "Law, Politics, and International Governance." In Christian Reus-Smit, ed., The Politics of International Law, 23871. Cambridge: Cambridge University Press. 


\title{
10 Law, politics, and international governance
}

\author{
Wayne Sandholtz and Alec Stone Sweet
}

The politics of international law are inextricably linked to the issue of governance. In this chapter we approach the central themes of the book by considering this vexed issue, developing four key arguments. First, we define and conceptualise institutions and governance so that any alleged distinction between law and politics becomes untenable or irrelevant. Our claim here directly addresses two of the three questions put forward by Christian Reus-Smit (in chapters 1 and 2) as animating this book: How should we think of international law and international politics? What is the relationship between the two? Our empirical discussion responds to the third question: How does rethinking these categories enable us better to understand contemporary international relations? We agree with Reus-Smit that international law and politics infuse and shape each other, although we understand this relationship somewhat differently. Second, we are concerned with the sources and uses of power in international society. Elaborating on the distinction drawn by Reus-Smit between realist and constructivist approaches, we distinguish normative-ideational power (influence through argumentation and suasion, dear to constructivists) from material-physical power (influence through the manipulation of threats and coercion, emphasised by realists). Third, we develop a relatively abstract model of how institutions emerge and evolve in two kinds of social settings: the dyadic and the triadic. Finally, we illustrate our theoretical ideas with reference to the development of triadic forms of governance in the context of the General Agreement on Tariffs and Trade (GATT), and dyadic in the case of forcible humanitarian intervention.

Our discussion proceeds as follows. In part one, we define our terms and concepts. In part two, we specify the conditions under which thirdparty dispute resolution will organise institutional change over time, 
using the transformation of the international trade regime as a case in point. In part three, we discuss how institutional change takes place in the absence of a third party, and explore the question of humanitarian intervention. In the conclusion, we consider the implications of our arguments for various theoretical projects in international relations and international law.

\section{Rules, dispute resolution, and institutional change}

We seek to explain some of the dynamics of institutional change, by which we mean the emergence of new, or the transformation of existing, rule systems. The basic components of our model operate on three levels of analysis:

- macro level: the rule system, or institutional environment, that enables and sustains social activity;

- micro level: the domain of action and decision making by individual actors;

- meso level: those structures - concrete and organisational, or abstract and discursive - that people create and use in order to coordinate rule systems and purposive action.

\section{Institutions}

Rule systems, or institutions, enable actors to conceive, pursue, and express their interests and desires, but also to co-ordinate those desires with other individuals. We take a broad view on social structure, heavily informed by what has by now become virtually generic social theory. ${ }^{1}$ Our conception of macro structure is congruent with what Douglass North calls 'institutions', variously: 'rules of the game', 'customs and traditions', 'conventions, codes of conduct, norms of behavior, statute law, common law, and contracts'. ${ }^{2}$ It encompasses James March and Johan Olsen's notion of 'rules': the 'beliefs, paradigms, codes, cultures, and knowledge' that permit us to 'identif[y] the normatively appropriate

\footnotetext{
${ }^{1}$ See Douglass C. North, Institutions, Institutional Change, and Economic Performance (Cambridge: Cambridge University Press, 1990); and Walter W. Powell and Paul J. Dimaggio (eds.), The New Institutionalism in Organizational Analysis (Chicago: University of Chicago Press, 1992).

${ }^{2}$ North, Institutions, pp. 3-6.
} 
behavior'. ${ }^{3}$ It is capable of equating norms, as Michael Taylor does, with 'ideologies' and 'culture', ${ }^{4}$ and with Harry Eckstein's view of 'culture' as a system of 'mediating orientations ... general dispositions of actors to act in certain ways in sets of situations'. ${ }^{5}$ And it can understand 'institutionalized rules', in Ronald Jepperson's terms, as 'performance scripts'.6

We see institutions as rule structures. Rules, of course, vary; they can be more, or less, formal, precise, and authoritative; and they may be more or less tied to organisational supports, including enforcement mechanisms. ${ }^{7}$ We could array institutions along a continuum. At the left end of the continuum are institutional settings that are relatively informal, with imprecise rules that are not binding on actors, and where there are no centralised monitoring or enforcement mechanisms. (This is not to say that these settings lack rules; social existence of any kind is impossible without norms, even if the norms in place are relatively informal and imprecise.) At the right end of the continuum are institutional contexts defined by rules that are highly formal, specific, and authoritative; these have the attributes that people associate with highly developed legal orders. Other institutions would fall between these two extremes.

At the international level, all established institutional structures would occupy different points on the spectrum. ${ }^{8}$ Some international institutions are highly formal, specific, and authoritative. The European

3 James March and Johan Olsen, Rediscovering Institutions: The Organizational Basis of Politics (New York: Free Press, 1989), p. 22.

${ }^{4}$ Michael Taylor, 'Structure, Culture and Action in the Explanation of Social Change', Politics and Society 17: 2 (1989), 135.

5 Harry Eckstein, 'A Culturalist Theory of Political Change', American Political Science Review 82: 3 (1988), 790.

${ }^{6}$ Ronald L. Jepperson, 'Institutions, Institutional Effects, and Institutionalism', in Powell and Dimaggio (eds.), The New Institutionalism in Organizational Analysis, p. 145.

7 See Alec Stone Sweet, Wayne Sandholtz, and Neil Fligstein, 'The Institutionalization of European Space', in Alec Stone Sweet, Wayne Sandholtz and Neil Fligstein (eds.), The Institutionalization of Europe (Oxford: Oxford University Press, 2001).

8 Alec Stone, in 'What is a Supranational Constitution?: An Essay in International Relations Theory', Review of Politics 56: 3 (1994), elaborated a continuum in which the rule structures constituting various international regime forms could be situated. The continuum captures three dimensions: degree of normative precision, degree of formality, and degree of organisational capacity to monitor compliance and punish non-compliance. In a recent special issue of International Organization, a research project on the 'legalisation' of international politics adopts, as an analytical/heuristic device or dependent variable, a continuum that largely reproduces these same elements. See Judith Goldstein, Miles Kahler, Robert Keohane, and Anne-Marie Slaughter (eds.), Special Issue on the Legalization of International Politics, International Organization 54: 3 (2000). 
Union (EU) now resembles, in important respects, a 'constitutionalised', quasi-federal polity. ${ }^{9}$ During the same period, the GATT ${ }^{10}$ developed an important degree of formality, precision, and authoritativeness, if less than the EU, which its mutation into the World Trade Organisation (WTO) took much further. ${ }^{11}$ Much of organised international relations fall further to the left on the continuum. The distinctive institution of modern international law that Reus-Smit describes in chapters 1 and 2 would thus be most developed near the right end of our spectrum.

As one moves along the continuum from left to right, the nature of political activity changes. The left end of the spectrum resembles what international relations scholars have traditionally referred to as 'anarchy', meaning not absence of order but the lack of formal structures of government and authoritative dispute resolution. At the left end, bargaining, negotiation, and coercion are standard modes of interaction. Toward the right side of the spectrum, politics are more structured by legal rules and judicialised dispute resolution. There are 'islands' of such institutionalised rules and governance structures in international relations, including the European Union, the WTO dispute resolution mechanism, and the world of transnational business. ${ }^{12}$ As Reus-Smit argues in chapter 1 , politics tends to be a qualitatively different activity within the framework of law than outside of it.

In the opening chapter to this volume, Reus-Smit makes a strong case for taking seriously the constitutive power of institutions, arguing that they can shape actors' identities, roles, and, therefore, their interests. Although we accept the logic of this argument, our chapter focuses on the relationship between institutions - law and norms - and observable behaviour, including the development of norm-based argumentation, legal discourse, and 'judicialised' politics. It is exceptionally difficult to assess relationships among institutions, identities, and interests as

\footnotetext{
${ }^{9}$ Eric Stein, 'Lawyers, Judges, and the Making of a Transnational Constitution', American Journal of International Law 75: 1 (1981); and Joseph H. H. Weiler, 'The Transformation of Europe', Yale Law Journal 100: 7 (1991).

${ }_{10}$ Robert E. Hudec, Enforcing International Trade Law: The Evolution of the Modern GATT Legal System (Salem, NH: Butterworth, 1993).

11 Ernst-Ulrich Petersmann, 'The Dispute Settlement System of the World Trade Organization and the Evolution of the GATT Dispute Settlement System Since 1948', Common Market Law Review 31: 6 (1994).

12 Alec Stone Sweet, 'Islands of Transnational Governance', in Martin Shapiro and Alec Stone Sweet, On Law, Politics, and Judicialisation (Oxford: Oxford University Press, 2002).
} 
they evolve in dynamic systems. Although we are comfortable with the notion that rule systems - and the flow of politics within institutions may alter the identities and preferences of actors, we content ourselves with providing the kind of evidence that those who would make such claims might use. But we do not directly address what we take to be the basic epistemological question: pursuant to some observable alteration of the institutional environment, is a given, stable shift in the observable behaviour of any actor or set of actors best explained by (1) a change in the actors' preferences or identities, or (2) a change in actors' strategies (with preferences fixed)?

Of course, institutions persist because they are in some sense functional constructions, whether in an old-fashioned anthropological or new-fashioned economistic sense. Among other things, they provide people with behavioural guidance, reduce uncertainty and transaction costs, and thereby facilitate social exchange and co-operation. Conceived more sociologically, any social setting, or organisational field, is nothing but a specific set of normative solutions to a specific set of social problems. Even accepting these points, two problems necessarily arise. First, institutions are abstractions. At best they constitute templates or choice-contexts for action. Put differently, because rule structures do not apply themselves, they are always at least relatively indeterminate. The precise nature, scope, and content of relevant duties and obligations can only be known (if at all) through processes of interpretation and application. Second, institutions, partly because they are abstract, can, in and of themselves, be a source of disputes that erupt between individuals. That is, a dispute may reveal tensions and inconsistencies within rule structures, at least with respect to that dispute. Thus, to the extent that any normative construct is in fact relevant to a particular situation, decision, or action, it can never be innocent of politics and the exercise of power.

In short, rule structures are at the heart of any dispute that might interest social scientists, for two reasons. First, the inevitable gap between general rules and specific actions means that the application of rules is always subject to interpretation and contestation. Second, because no complex rule system provides comprehensive solutions to conflicts among all of its constituent components, tensions and contradictions among norms are also commonplace, and likewise fuel debate. When normative disputes of these kinds arise, actors bring to bear both normative and material powers, and thus the distinction between law and politics vanishes. 


\section{Actors and action}

Whenever individuals interact with each other, they inevitably build norm-based structures, rules of language and action considered appropriate to a given set of interactions. We assume that in these interactions, people are rational, in the sense of being utility maximisers. Within constraints imposed by institutions, resource limitations, and imperfect information, actors will seek to develop optimal strategies with which to pursue their interests. The game theoretic point that rules systems structure strategic calculation (a change in the rules of the game will always lead to different play, and thus different outcomes), simply privileges institutions as crucial factors generating political outcomes. Further, institutions possess the capacity to help mitigate imbalances of material or physical power between actors. Indeed, normative systems typically announce rules that either (1) do not take into account such asymmetries, or (2) invoke principles (such as equity or fairness) that give advantages to the weaker party. We do not deny that seemingly 'power-neutral' norms often reflect underlying distributions of power. Our point is rather the contrary: norms are always implicated in politics. Last, in situations where information is imperfect in some meaningful way, institutions will be all the more important ${ }^{13}$ to how actors make sense of their world and select courses of action.

If we see actors as bearers of interests, that is not all we see. Rationality, in the utility-maximising sense, is not the only logic of action (or micro-foundation) relevant to institutional change. As a diverse set of social scientists have noticed and begun to theorise, ${ }^{14}$ norms tend to develop in processes that are both incremental and path dependent. The deep structures of this process are cognitive and pre-social: human beings have native or 'instinctual' capacities for language. Indeed, we would argue that the ability to think about rules in complex ways reasoning from precedent and weighing contradictory norms - is as innately human as the 'language instinct' ${ }^{15}$ Robert Sugden points out that 'ordinary people with limited rationality' find little difficulty in solving co-ordination problems that the fully rational players in game theory

13 See North, Institutions.

14 For example March and Olsen, Rediscovering Institutions, chapter 2; Alec Stone Sweet, 'Judicialization and the Construction of Governance', Comparative Political Studies 32: 2 (1999); and Robert Sugden, 'Spontaneous Order', Journal of Economic Perspectives 3: 4 (1989).

${ }^{15}$ The phrase borrows the title of a superb book by Steven Pinker, The Language Instinct (New York: W. Morrow, 1994). 
find intractable, and suggests that the ability to work with conventions and norms is innate, even biological. ${ }^{16}$ We observe people reasoning and talking about rules in every kind of social group. That observation lends some prima facie credibility to the notion that normative reasoning, based on analogies that link rules to situations, is at least as innate and fundamental to humans as utilitarian calculation.

For cognitive psychologists, analogical reasoning is the process through which people 'reason and learn about a new situation (the target analog) by relating it to a more familiar situation (the source analog) that can be viewed as structurally parallel'. ${ }^{17}$ The ability to construct analogies is widely considered to be an innate part of thinking. ${ }^{18}$ Unfamiliar situations, those that individuals cannot understand through their generalised knowledge, stimulate the formation of analogies, which are used to conceptualise and to find solutions to problems. ${ }^{19}$ The set of potential source analogs is defined jointly by (1) the specific, immediate problem to be resolved (or situation to be conceptualised), and (2) the past experiences of the individuals constructing the analogy. Foreshadowing somewhat, we view normative deliberation, including legal argumentation and judging, as a species of analogical reasoning: actors reason from existing institutions (the equivalents of source analogs), to characterise the interplay of new fact contexts and interests raised by a dispute (the target analog), and to find an appropriate solution to it. ${ }^{20}$ As Reus-Smit argues in chapter 2, actors simultaneously engage in purposive and instrumental logics (maximising) and in logics of obligation and justification (or normative reasoning).

16 Sugden, 'Spontaneous Order', 89, 95.

17 Keith Holyoak and Paul Thagard, 'The Analogical Mind', American Psychologist 52: 1 (1997), 35.

18 Mark Keane, Analogical Problem Solving (Chichester, UK: Ellis Horwood Ltd, 1988); Stella Vosniadou and Andrew Ortony (eds.), Similarity and Analogical Reasoning (Cambridge: Cambridge University Press, 1989); Keith Holyoak and Paul Thagard, Mental Leaps: Analogy in Creative Thought (Cambridge, MA: MIT Press, 1995); and Richard Mayer, Thinking and Problem Solving: An Introduction to Human Cognition and Learning, 2nd edn (New York: W. H. Freeman \& Co, 1992).

19 Keane, Analogical Problem Solving, p. 103.

20 See James Murray, 'The Role of Analogy in Legal Reasoning', UCLA Law Review 29: 4 (1982); Cass Sunstein, 'On Analogical Reasoning', Harvard Law Review 106: 3 (1993); Garry Marchant, John Robinson, Urton Anderson, and Michael Schadewald, 'Analogical Transfer and Expertise in Legal Reasoning', Organizational Behavior and Human Decision Processes 48: 2 (1991); and Garry Marchant, John Robinson, Urton Anderson, and Michael Schadewald, 'The Use of Analogy in Legal Argument: Problem Similarity, Precedent, and Expertise', Organizational Behavior and Human Decision Processes 55: 1 (1993). 


\section{Dispute resolution and governance}

Typical sources of conflicts can be listed but need not detain us much. An actor may succumb to temptations to renege on promises made in order to obtain advantage (the prisoner's dilemma). As circumstances change, actors may come to different views on the legitimacy of the existing rules that govern a relationship, and seek to replace those with new ones. Or, as norms evolve, and social interactions become more complex, actors may disagree about if and how a specific set of rules is to be applied to the situation in which they find themselves. Last, some rule systems offer actors more than one normatively defensible means of resolving a conflict, even when the disputants agree about the nature or type of dispute they are in.

Institutions facilitate dispute resolution. They do so in three ways. First, at the level of the single actor, a norm can prevent disputes from arising in the first place, by providing individuals with behavioural guidance, and by structuring choices concerning compliance. Second, once a dispute has erupted, norms may provide the contracting parties with the materials for settling the dispute on their own, dyadically as it were, to the extent that norms furnish the bases for evaluating both the disputed behaviour and potential solutions to the conflict. Third, existing rule systems help third-party dispute resolvers do their jobs, by providing templates for determining the nature of the dispute and an appropriate solution.

We define governance as the process through which rule systems are adapted to the needs and purposes of those who live under them. ${ }^{21}$ Modes of governance are social mechanisms for constructing rules and for applying them to concrete situations. Given changing circumstances, all social systems require such mechanisms if they are to reproduce themselves. We focus here on how two types of governance serve both to resolve disputes and to evolve institutions. Both are meso-level structures that, under certain conditions, will forge linkages between macro abstractions and micro particularities. To the extent that they operate with effectiveness, they will help to bind together, and mediate between, the domain of rules and the domain of action, giving institutions at least a measure of determinancy that they would otherwise lack.

The first structure, the argumentation framework, is cognitive and discursive. Argumentation frameworks (what Anglo-Saxon lawyers

${ }^{21}$ Stone Sweet, 'Judicialization and the Construction of Governance'. 
often call doctrine) organise how disputants make normative claims and engage one another's respective arguments. Following Giovani Sartori, ${ }^{22}$ these structures can be analysed as a series of inference steps, represented by a statement justified by reasons (or inference rules), that lead to a conclusion. Legal frameworks typically embody inconsistency, to the extent that they offer, for each inference step, both a defensible argument and counter-argument, from which contradictory - but defensible - conclusions can be reached.

Although we have argued that rule systems, including law, are indeterminate, argumentation frameworks provide a measure of (at least short-term) systemic stability, to the extent that they condition how actors pursue their self-interest, social justice, or other values through normative deliberation. To be effective in this discursive politics, actors have to be able to identify the type of dispute in which they are involved, reason through the range of legal norms that are potentially applicable, and assess available remedies and their consequences. Argumentation frameworks, being a formalised analog, help actors do all of these things, and more. They require actors not only to engage in analogic reasoning, but in argumentation. Considered in more sociological terms, they are highly formal, meso-level structures that connect institutions (such as the law) to the domain of individual agency, by sustaining deliberation about the nature, scope, and application of norms. In culturalist terms, they enable specifically placed social actors to adjust abstract 'guides to action' to 'the relentless particularity of experience', ${ }^{23}$ on a continuous basis.

The second structure is the triad, where two parties to a dispute delegate their conflict to a third party for resolution. All forms of dispute resolution can be classified as either dyadic or triadic. The distinction is straightforward. In dyadic contexts, the parties to a dispute seek to define a solution between themselves, that is, without recourse to an external mediator, arbitrator, or judge. In that sense, we might think of dyadic settings as formally anarchic (which is not to say without order), because there exists no authoritative dispute resolver outside the dyad. Dyadic dispute resolution can thus take multiple forms: imposition (a stronger party coerces a weaker one), negotiation, persuasion. Such forms of dispute resolution are ubiquitous; we see them between spouses, labour and management, many interstate conflicts, and so on.

22 Giovanni Sartor, 'A Formal Model of Legal Argumentation', Ratio Juris 7: 2 (1994).

23 Eckstein, 'A Culturalist Theory of Political Change', 795-6. 
Moreover, describing a dispute resolution process as dyadic does not mean that only two actors are involved. Multilateral disputes (that is, involving more than two parties), can be seen as a collection of linked bilateral relationships. The label 'dyadic' simply refers to the absence of an outside adjudicator.

Triadic dispute resolution, naturally, embraces all settings in which, in addition to the parties themselves, there is a 'third party' (which can also be a collectivity of multiple actors, including enforcers), who assists in finding, or authoritatively determining, resolution of the dispute. To move from dyadic to triadic systems of dispute resolution is to move from anarchy to hierarchy. Empirically, forms of triadic dispute resolution vary along a continuum that roughly stretches from mediation to arbitration to adjudication. As we move left to right on this continuum, the authority of the triadic entity, vis-à-vis the parties, is enhanced and institutionalised in ever more formal rules and procedures.

We view judging as a species of analogic reasoning which produces marginal adjustments to the law over time. Further, to the extent that judgements are motivated with reasons, and to the extent that some minimally robust conception of precedent operates, dispute resolution will serve not only to construct the law but to delineate argumentation frameworks. Where adjudication is both intensive and effective, prior records of decision-making, curated by legal actors as precedents, will cluster and congeal in argumentation frameworks. These frameworks will organise normative deliberation and analogical reasoning, and help to reinforce the authority of the triadic entity.

Under certain conditions, dispute resolution will provoke normative innovation. Where these conditions are met, the sequence - rule structures $>$ social exchange $>$ disputing $>$ dispute resolution (through normative deliberation or delegation to a third party) $>$ rule-making $>$ institutional change $>$ social exchange - will tend to reproduce itself in a self-reinforcing process. We will try to defend these claims in the next two sections.

\section{Triadic dispute resolution and governance}

The causal relationship between triadic dispute resolution (TDR) and rule innovation is well-known, and has been theorised in quite diverse theoretical languages. ${ }^{24}$ If the triadic entity resolves disputes in a

${ }^{24}$ For example, H. L. A. Hart, The Concept of Law, 2nd edn (Oxford University Press, 1994), chapter 7; Karl Llewellyn, 'The Normative, the Legal, and the Law-Jobs: The 
minimally respectable (rather than arbitrary or a fraudulent) manner, and gives reasons for her decisions, then these decisions will contain materials for consolidating existing, or building new, norms. Given two conditions, TDR is likely to generate powerful pedagogical - or positive feedback - effects, to be registered on subsequent social exchange and dispute resolution. First, actors must perceive that they are better off in a world with TDR than without it. If they do, and if they are rational, they will evaluate the rulefulness of any potential action and anticipate the probable outcome issuing from TDR. Second, the dispute resolver must understand that her decisions have some authoritative - that is, precedential - value.

If these conditions are met, then the more people go to a triadic entity, the more that entity will exercise authority over the relevant rule system. A virtuous circle is thereby constructed: to the extent that TDR is effective, it will reduce the costs of social exchange; as social exchange increases in scope, so will the demand for the authoritative interpretation of rules; as TDR is exercised, the body of rules that constitutes normative structure steadily will expand, becoming more elaborate and differentiated; these rules then will feed back onto dyadic relationships, structuring future interactions, conflict, and dispute resolution.

If exercised on an ongoing and effective basis, TDR is likely to constitute a crucial mechanism of social cohesion and change, by propagating and sustaining the development of expansive argumentation frameworks. To put it in constructivist terms, triadic governance will help to co-ordinate the complex relationship between structures and agents, ${ }^{25}$ helping to constitute and reconstitute both over time. In rationalist terms, the move from the dyad to the triad replaces games, like the prisoner's dilemma or chicken, with an entirely different strategic context. Although game theorists have begun to notice the challenge, ${ }^{26}$ they have had difficulty modelling 'triadic'. ${ }^{27}$

Problem of Juristic Method', Yale Law Journal 49: 8 (1940), 1373; Alf Ross, On Law and Justice (London: Stevens and Sons, 1958); Martin Shapiro, 'Stability and Change in Judicial Decision-Making: Incrementalism or Stare Decisis?', Law in Transition Quarterly 2: 3 (1965); and Stone Sweet, 'Judicialization and the Construction of Governance'.

25 Anthony Giddens, The Constitution of Society: Outline of the Theory of Structuration (Berkeley: University of California Press, 1984).

${ }^{26}$ For example, Randall L. Calvert, 'Rational Actors, Equilibrium, and Social Institutions', in Jack Knight and Itai Sened (eds.), Explaining Social Institutions (Ann Arbor, MI: University of Michigan Press, 1995).

27 See the exchange between Alec Stone Sweet, 'Rules, Dispute Resolution, and Strategic Behavior', Journal of Theoretical Politics 10: 3 (1998) and Georg Vanberg, 'Reply to Stone Sweet', Journal of Theoretical Politics 10: 3 (1998). 
We now examine the impact of TDR on the international trade regime, an arena in which judicial power had been initially, and by design, excluded. By judicial power, we mean the capacity of a triadic dispute resolver to authoritatively determine the content of a community's normative structure. In the GATT, an international treaty established rules governing relations between states; yet the regular use of TDR led to the mutation of these relations, and a new regime was thereby constituted. We use the term 'judicialisation' as shorthand for this mutation.

\section{The judicialisation of the international trade regime}

When the GATT (1948) entered into force and was institutionalised as an organisation, 'anti-legalism' reigned..$^{28}$ Diplomats excluded lawyers from GATT organs and opposed litigating violations of the treaty. In the 1950s, TDR emerged in the form of the panel system. Panels, composed of three to five members, usually GATT diplomats, acquired authority through the consent of two disputing states. In the 1970s and 1980s, the system underwent a process of judicialisation. States began aggressively litigating disputes; panels began treating the treaty as enforceable law, and their own interpretations of that law as constituting authoritative precedents; jurists and trade specialists replaced diplomats on panels. The process generated the conditions necessary for the emergence of the compulsory system of adjudication now in place in the WTO.

\section{Normative structure and dispute resolution}

The GATT is the most comprehensive commercial treaty in history, today governing more than five-sixths of world trade. In the 1955-74 period, membership jumped from 34 to 100 states; 124 states signed the Final Act of the Uruguay Round (establishing the WTO) in 1993. The treaty's core provision is a generalised equal treatment rule, the most favoured nation (MFN) principle, which rests on reciprocity: each party to the GATT must provide to every other party all the advantages provided to other trading partners. The treaty further prohibits, with some exceptions, import quotas. The organisation also supports an interstate forum for legislating trade law: eight 'rounds' have reduced most tariffs to the point of insignificance and, less successfully, restricted non-tariff barriers to trade.

The treaty exhorts members to settle their disputes dyadically, in accordance with GATT rules. The potential for a trade conflict to move ${ }^{28}$ Olivier Long, Law and its Limitations in the GATT Multilateral Trade System (Boston: Martinus Nijhoff, 1985), pp. 70-1; and Hudec, Enforcing International Trade Law, p. 137. 
to a triadic stage was implied: if state A could demonstrate that it had suffered damages due to violations of GATT law committed by state B, state A could be authorised by the GATT membership as a whole to withdraw advantages or concessions that it would normally be required to accord state B. Almost immediately, however, member states invented the panel system to resolve disputes.

As institutionalised in the 1950s, the system blended mediation and consensual adjudication, against a backdrop of ongoing dyadic dispute resolution. Defendants could not be compelled to participate in TDR. By denying consent, a state could block the construction of a panel, reject proposed panelists, and refuse to allow a ruling to be reported. Relative to compulsory forms of adjudication, the system appeared grossly inefficient. The original function of panels, however, was to facilitate dyadic conflict resolution, not to punish violators or to make trade law. Diplomats, trade generalists who saw expedience in flexible rules and detriment in rigid ones, sat on panels. When mediation failed, panels could, with the consent of the disputants, resolve conflicts according to relevant treaty provisions.

Before 1970, states did not exploit the connection between TDR and rule-making. But, being both imprecise and rigid, the regime's normative structure proved insufficient to sustain optimal levels of trade over time. The treaty mixes a few hard obligations (the MFN norm and tariff schedules) with a great many statements of principle and aspiration. Despite its flexibility, important GATT provisions could be revised only by unanimous consent. Although the success of the GATT was partly due to normative imprecision - the more vague a rule, the easier it was for states to sign on to it - textual imprecision was often locked in by the unanimity requirement. The tension is obvious. Achieving optimal levels of exchange partly depends on the continuous adaptation of abstract rules to concrete situations, but the GATT legislator was ill-suited to perform this adaptation for the trade regime.

\section{Building the triad}

Beginning in 1970, the largest trading states turned to the panel system not just to resolve their trade conflicts, but to make trade policy. After falling into desuetude in the 1960s (only seven complaints filed), TDR exploded into prominence afterwards. Of the 207 complaints filed through 1989, 72 per cent were filed after 1969, and 56 per cent after 1979. The four largest trading states - Canada, the EC, Japan, and the 
US - dominated panel proceedings: in the 1980s, over 80 per cent of all disputes registered involved two of these four states.

The expansion of global exchange, and the domestic political consequences of that expansion, broadly explain the renaissance of TDR. Bilateral exchange among the big four (Canada, the EC, Japan, and the US) rose from $\$ 15$ billion in 1959, to $\$ 44$ billion in 1969, to $\$ 234$ billion in 1979 , to $\$ 592$ billion in 1989. As trade redistributed resources and employment across productive sectors within national economies, domestic actors mobilised to protect their interests. And as these economies came to produce virtually the same products for export (for example, electronics, automobiles, food products), trade relations were easily interpreted in zero-sum terms.

By 1970, new forms of protectionism had proliferated, the Gold Standard currency regime was rapidly disintegrating, and the American trade deficit had become chronic. The need for clearer rules and better compliance was acute. At the same time, the GATT legislator had failed to liberalise certain crucial sectors (for example, agriculture), to dismantle the mosaic of non-tariff barriers that had emerged in response to tariff reduction (for example, restrictive licensing policies and production standards), and to regulate other practices that distorted trade (for example, subsidies). Led by the US, which was also groping for ways to reduce its trade deficit, governments turned to the panel system. ${ }^{29}$

Three general motivations animated the move to TDR. In the vast majority of instances, states initiated complaints in order to induce other states to modify their domestic trading rules. As we will see, GATT panels proved to be a relatively effective means of doing so. Second, states appealed to panels in order to alter, clarify, or make more effective existing GATT rules. This motivation overlaps the first, since virtually all trade disputes are translatable into a general argument about the meaning and application of specific treaty provisions. Disputants worked to convince panels to adopt their versions of GATT rules, in order to encourage the spread of practices they considered lawful and to discourage practices they considered unlawful. Third, while difficult to verify,

${ }^{29}$ Disputants tend to litigate what diplomats failed to legislate. Conflicts over agriculture and subsidies paralysed trade negotiations, and they also dominated TDR processes after 1970. Of 115 complaints filed in the 1980s, 51 (44 per cent) concerned trade in agricultural goods. Of the 44 disputes filed citing one of the GATT codes, 21 (or 48 per cent) relied on rules found in the subsidies code. 
governments sometimes participated in TDR to delegitimise - and thus facilitate the revision of - their own trade practices. ${ }^{30}$

To maximise their success, governments had a powerful interest in replacing diplomats and generalists with lawyers and trade specialists. The Americans understood this immediately; the Nixon Administration turned GATT litigation over to trade lawyers in 1970. By that year, the enormous complexity of trade disputes - the resolution of which requires determining (a) the extent to which a specific domestic law or administrative practice conforms with treaty provisions, and (b) the extent to which, in cases of non-conformity, such a law or practice had caused, or might cause, trade distortions - was far beyond the capacity of anyone but the lawyer and the expert. Once introduced by the Americans, lawyerly discourse perpetuated itself. Lawyers filed detailed legal briefs, attacking or defending particular national policies; faced with detailed questions, panels gave detailed answers; lawyers then understood the reasoning supporting such answers as guidelines for future litigation strategies. The EC and Japan initially resisted the move to legalism; but they became active participants after being bombarded with complaints by the US and Canada. By the early 1980s, all of the major trading states had armed their Geneva staffs with permanent legal counsels.

\section{Triadic governance}

In activating TDR, GATT members delegated to the panel system an authority that is inherently governmental. As panels exercised this authority, they generated three sets of political outcomes; these outcomes can only be explained by attending to the dynamics of TDR.

First, panels altered the terms of global exchange by provoking, with their decisions, the modification of national trading rules. If complied with, every decision declaring a national rule or practice inconsistent with GATT rules concretely impacts the lives of importers, exporters, consumers, and producers. Activating TDR worked in favour of plaintiff

${ }^{30}$ In 1988, the US instituted proceedings against the EC's payment regime for oilseed processing. A panel ruled that the programme both discriminated against foreign processors and functioned as an indirect subsidy for EC producers. France, invoking the consensus norm, sought to suppress the decision but the EC adopted the ruling over France's objection. The EC then replaced the payment system with a new one. In effect, the EC had used TDR to delegitimise an outmoded, costly programme of which France had blocked revision within internal EC law-making processes. Complaint \#179, US v. EC (22 April 1988). Complaints have been assembled and numbered chronologically in Hudec, Enforcing International Trade Law, Appendix. We use Hudec's reference system to refer to cases in this and subsequent notes. 
states: plaintiffs enjoyed a success rate of 77 per cent in the 1948-89 period, rising to 85 per cent in the 1980s. The rate of compliance with adverse decisions was 74 per cent in the 1980-9 period.

To resolve many of the most complex disputes, panels had no choice but to reach far into national jurisdictions. Thus, a panel ruled that a US law providing a special administrative remedy for patent infringement claims involving imported goods violated the GATT since defendants stood a better chance of winning in district courts. ${ }^{31}$ To arrive at this decision, panelists investigated US litigation rates and judicial outcomes, concluding that biases in the administrative procedure constituted a discriminatory bias affecting trade. In separate cases, panels required Canada to force provincial governments to remove taxes on foreign gold coins, and to force provincial liquor boards to change regulatory practices favouring domestic alcoholic beverages. ${ }^{32}$

Panels reinforced their influence over policy outcomes by elaborating guidelines for state compliance. In explaining why a given national practice was or was not inconsistent with GATT obligations, panels suggested GATT-consistent versions of the practices in question. (Such behaviour inheres in triadic rule-making.) In 1986, to take just one instance, the EC attacked the Japanese system of taxation for alcoholic beverages. ${ }^{33}$ The system, which classified products into dozens of categories corresponding to different tax rates, resulted in importers paying higher taxes than Japanese producers for similar products. The panel declared the system to be inconsistent with the treaty, and announced a general rule: national tax schemes must treat all 'directly competitive' products equally. It then elaborated a hypothetical system based on equal treatment, demonstrating precisely what a lawful system would look like. The Japanese subsequently adopted a system similar to the panel's.

Second, in response to the exploitation of TDR by states for their own political purposes, panels reinvented themselves as judges, the authoritative interpreters of the regime's normative structure. This process can be tracked and measured. As the number and complexity of complaints grew, panels produced longer decisions and increasingly precise interpretations of treaty provisions. ${ }^{34}$ In complicity with GATT litigators,

31 Complaint \#162, EC v. US (29 April 1987).

32 Complaint \#132, South Africa v. Canada (3 July 1984); complaint \#139, EC v. Canada (12 February 1985).

33 Complaint \#154, EC v. Japan (6 November 1986).

34 In the 1948-69 period, the average length of reported rulings was seven pages; in the 1970-9 period, the average length rose to fifteen pages; after 1985, the average reached 
citations to past decisions became increasingly common and expected. Once constructed as a precedent-based discourse about the meaning of GATT rules, panel decisions became a fundamental source of those rules. (Such rule-making took place despite the absence of a doctrine of stare decisis in international law, and despite the refusal of the member states to formally recognise the precedential value of decisions.) Certain treaty provisions (for example, the MFN norm, rules governing taxation and quotas) emerged as sophisticated, relatively autonomous domains of legal discourse, replete with their own stable of argumentation frameworks. ${ }^{35}$ By the 1980 s at the latest, the rules in these domains could only be understood in light of the argumentation frameworks curated by the panels. Although the substance of this law is far beyond the scope of this chapter, panels ratcheted up national responsibility to justify any claimed exceptions to liberal trading rules which, among other things, served to expand the grounds for future complaints.

Panels also generated rules governing their own jurisdiction. ${ }^{36}$ By the end of the 1980s a stable case law asserted that, among other things, panels could:

- not only review the consistency of national acts with the treaty, but could also detail what kinds of similar, if hypothetical, acts might violate GATT rules;

- announce answers to questions not raised by plaintiffs, but which were nevertheless relevant to other trade disputes;

- report a ruling even if the dispute on which it was based had become moot (for example, as a result of prior dyadic settlement), in order to clarify GATT rules and thus facilitate future dyadic and triadic dispute resolution.

forty-eight pages. Robert E. Hudec, 'The Judicialization of GATT Dispute Settlement', in M. H. Hart and D. B. Steger (eds.), In Whose Interest?: Due Process and Transparency in International Trade (Ottawa: Center for Trade Policy and Law, 1992), p. 11.

${ }_{35}$ Breaking down GATT complaints filed in the 1980s with reference to the article of the Agreement in dispute provides some indication of the relative density of these areas. In 115 filings, disputants invoked specific parts of the Agreement 212 times. Four areas of the law account for 71 per cent of total claims: the MFN norm (arts. 1 and 2, 21 per cent); non-discrimination in taxation and regulation (art. 3, 10 per cent); elimination of quotas (arts. 11, 13, 34 per cent); and nullification or impairment of benefits (art. 23, 6 per cent). Of the 66 instances in which the special codes were invoked, the codes on subsidies were involved 41 times (62 per cent). See Alec Stone Sweet, 'The New GATT: Dispute Resolution and the Judicialization of the Trade Regime', in Mary L. Volcansek (ed.), Law Above Nations: Supranational Courts and the Legalization of Politics (Gainsville: University Press of Florida, 1997).

${ }^{36}$ Hudec, Enforcing International Trade Law, pp. 258-65. 
Third, judicialisation processes reconstructed how states understood the nature of their own regime. States reacted to the development of a rule-oriented mode of governance not by suppressing it, but by adjusting to it. Their lawyers filed more and increasingly legalistic complaints, and their diplomats ratified judicialisation in official agreements. Thus, the 1979 'Understanding' on dispute settlement placed the GATT's system on legal footing for the first time, codified dispute settlement procedures, and gave legal force to panel reports. In 1981, citing the overwhelming complexity of litigation facing panelists, states permitted the establishment of a Legal Office charged with rationalising procedures and providing support for panel members. And in the Uruguay Round (1986-92), states asked an autonomous group of experts to study how TDR could be strengthened. The fruit of their efforts was the legal system of the WTO.

The Final Act of the Uruguay Round transformed the GATT into the WTO, providing for a system of compulsory adjudication of disputes. The new rules: automatically confer jurisdiction to panels upon the reception of a complaint; no longer permit unilateral vetoes of any stage by either party; and provide for a broad range of measures to punish non-compliance. An independent appellate body is charged with handling appeals from panels. The body is composed of seven members who possess 'demonstrated expertise in law'.

Undeniably, the move from consensual to compulsory TDR could not have taken place without a convergence in the preferences of the most powerful trading states. The US had advocated more efficient dispute settlement since the 1970s. The Americans had even taken measures in domestic law to unilaterally punish those who blocked or refused to comply with GATT decisions; and the move provoked the EU to adopt similar measures. Facing a trading world in which GATT rules might be enforced unilaterally by the most powerful states, the rest of the world joined the US and Europe in working to strengthen multilateralism.

But, if converging state interests were crucial to the enhancement of TDR in the GATT, judicialisation generated the context necessary for that convergence. Judicialisation is socialisation. As states gained experience with dispute settlement, as panels performed their dispute resolution functions, as a stable case law enhanced legal certainty, GATT members could afford to view triadic rule-making as a useful, costeffective guarantor of regime reciprocity. In the 1980s, states did not consider abolishing the panel system, but debated how best to enhance 
it. By the end of the decade, a collective future without effective TDR was no longer a serious option.

\section{Dispute resolution and normative change in the dyadic context}

Though islands of triadic dispute resolution have emerged in international relations, most international interactions are dyadic. Disagreements between international actors are sometimes subject to resolution by a third party, through arbitration, mediation, or referral to supranational courts or other formal mechanisms. But in many instances, when actors contest the appropriateness of specific acts, or debate the meaning of relevant norms, they do not or cannot refer the dispute to an outside arbiter. Instead, each disputant seeks to persuade her rival, and third parties, that her understandings of the rules and of the disputed acts are correct. International actors deploy both arguments and material power to bring others to their view. At one extreme, those with sufficient power resources can impose their preferred solutions on other actors, though they will simultaneously offer arguments designed to show that their choices are also normatively justified. At the other extreme, when no single actor can impose a solution, normative arguments about what course of action is justified are crucial in establishing consensus.

The regular deployment of material resources, whether as incentive or punishment, underlies the persistent image of international relations as structured fundamentally by relations of power. The realist and neorealist traditions deny that norms and suasion play any independent role in international politics; actors offer arguments and invoke norms, but only as decoration for what they would have done in any case. Material structures are the only ones that count. Thus the powerful do what they will and the weak accept what they must.

We argue that even actors with the greatest material resources do not operate outside of normative structures. In the dyadic portions of international relations, where there is no authoritative dispute resolver, the dynamic of normative evolution is not simply reducible to the exercise of power. Three related arguments support this assertion. First, the range of disputes that can be settled by the unilateral application of material power or coercion is restricted and probably shrinking. Indeed, military force (the ultimate currency in realist and neorealist approaches) is simply not a factor in the vast majority of disputes. Indeed, the frequency of wars among great powers has been in secular decline, and 
essentially non-existent since the Second World War. Thus the great powers can impose armed faits accomplis in a small set of instances, and these (in practice) only vis-à-vis weak or collapsed states. Second, in the far more common situations where military force is not an option, the great powers operate within a set of institutions (rules) most of which they did not devise but rather inherited. They must therefore employ persuasion, and for that they must assert their claims in terms of existing argumentation frames. Third, to the extent that powerful actors internalise the rules, their values, goals, and choices are shaped from within by normative structures that have been 'domesticated', a point to which we return in the conclusion.

\section{Normative change in the dyadic context}

In both dyadic and triadic settings, the inevitable gap between rules and actions generates disputes. As actors seek to resolve disputes, they reason by analogy, invoke precedents, and give reasons, whether their audience is a judge or a set of other governments. Two significant differences, however, distinguish dyadic international relations from triadic. First, in the dyadic realm, the dispute resolution process is less formalised. As a consequence, it often resembles interstate bargaining, as governments seek to persuade, and pressure, each other. Because the process in general is less formal, the body of precedents available to disputants is less formalised, which means that precedent establishes a broader, less clearly delineated argumentation frame. Second, because the discursive frame is more open and the process non-formalised, the deployment of power resources is less mediated by institutions than it is in a triadic setting.

Even so, the evolution of international norms in dyadic contexts follows a cyclical pattern similar to the one we saw in the triadic context. The cycle begins with the constellation of existing norms, which provides the normative structure within which actors decide what to do and evaluate the behaviour of others. Because rules cannot cover every contingency, and because conflicts among rules are commonplace, actions regularly trigger disputes. The arguments are about which norm(s) apply, and what the norms require or permit. Actors assert analogies between the act in question and some set of prior cases. When the analogy is persuasive, other actors will agree that the current dispute should fall under the same norms that covered the earlier (analogised) cases. But the argument does not end there, for it remains to be determined 
what the norms require in the present instance. Again, players argue by analogy with similar cases, in order to establish how the rules should apply to the case in dispute (if there are mitigating factors, if the case qualifies as an exception, and so on).

Even powerful states must make their case in terms of an existing normative context. And even governments of the most dominant states do not always prevail in these normative debates. As an illustration, the case of the United States in its post-Cold War 'unipolar moment' is quite instructive. The United States has not always been able to win important arguments, for example, with respect to Iraq. Even important friendly states (France, Germany, Russia) refused to support Security Council authorisation of the use of force against Iraq. The United States and its allies proceeded with war anyway, and the arguments about the effect of the war on international norms will continue for some time. Though other states were unable to prevent the US-led invasion of Iraq, they will be able to penalise the United States for what many governments view as a violation of international rules.

The outcome of any discourse is to change the norms under dispute. If everybody agrees that the norms apply without qualification, then the norms have been strengthened and the scope of their application clarified. If the relevant actors agree that the disputed act qualifies as a justified exception to the norms, then the scope of their application has also been clarified (the proliferation of exceptions, of course, can weaken a rule, which is also a norm change). If the participants in the discourse fail to reach consensus (as with Iraq), then that also modifies the norms in question, leaving their status weakened or ambiguous. In contrast with the triadic situation, where judges must make a decision, in the dyadic context, nothing compels actors to reach a determination. Thus disagreements over the meaning of the rules, and over the justifiability of specific acts, can continue unresolved over long periods of time.

The crucial point, however, is that the cycle of normative change has completed a turn. In a given normative structure, actions trigger disputes. Argument ensues, grounded in analogies with previous cases. The outcomes of these discourses (which also include the deployment of power) modify the rules, whether by making them stronger or weaker, clearer or more ambiguous. The cycle returns to its starting point, the normative structure, but the normative structure has changed. The altered norms establish the context for subsequent actions, disputes, and discourses. 


\section{The case of forcible humanitarian intervention}

Since 1990, a series of humanitarian crises has thrown into relief a tension between two sets of fundamental international norms. On the one hand, sovereignty rules traditionally prohibited intervention in the internal affairs of other states; on the other, the international community has clearly made human rights a matter of collective concern and universal norms. The question that pits these concerns against each other is: under what conditions may armed intervention be justified to halt massive human rights abuses occurring within the territory of a sovereign state? The society of states has confronted that question directly in several cases over the past decade; we assess a series of such cases beginning with the question of safe havens in northern Iraq in 1991 and ending with East Timor in 1999.

The resulting disputes over humanitarian intervention have generated precisely the kind of cycle we theorised above: rules provide the social context for action, specific acts trigger disputes, disputes provoke discourses, and discourses lead to modification of the rules. As a result of this evolution, international society has developed rules that permit, though they do not require, forcible intervention to halt grievous, widespread human rights violations. ${ }^{37}$

The United Nations Security Council has provided the chief institutional forum for the disputes and discourses over the legitimacy of humanitarian intervention.

Precedent works in the dyadic world roughly as it does in the triadic, through the creation of analogies. If humanitarian intervention was permitted in A, and the case of B is similar in important respects, then there is a plausible justification for intervening in B. Put differently, once the Security Council has permitted intervention in one case, it becomes much more difficult to argue that the rules prohibit intervention in a similar instance. Furthermore, when states do object to a proposed intervention, they must offer counter-arguments permitted by the argumentation framework. Each subsequent similar decision strengthens the discursive weight of the emerging norm. Thus participants in Security Council deliberations devise their arguments in light of that body's prior decisions (as parties pleading before a court in the triadic setting fashion their arguments with a view to prior judgements and opinions).

37 See Wayne Sandholtz, 'Humanitarian Intervention: Global Enforcement of Human Rights?', in Alison Brysk (ed.), Globalization and Human Rights (Berkeley: University of California Press, 2002). 
The proposition that participants in Security Council debates will develop and use argumentation frameworks by deploying analogies and precedents is not as obvious as it might appear. Indeed, Security Council members face substantial incentives to deny that precedents play any part in their decision-making, for at least two reasons. First, the members of any given Security Council will prefer to maximise their own discretion. They will therefore tend to deny the notion that their decisions should be constrained by what an earlier Council may have determined. This is especially true since the composition of the fifteen-member Security Council regularly changes (aside from the five permanent members). This is not the same as the normal turnover in personalities sitting on a court or in a legislature, because it is not just the individuals but the countries represented that rotate.

Second, with specific reference to humanitarian intervention, Security Council members will consistently attempt to maximise the normative protections of state sovereignty, and to minimise any dilution of them. The reason for this is straightforward: ambassadors in the Security Council represent the governments of states, which have an interest in preserving their own autonomy from outside intervention. From the perspective of any given government, any precedent must be seen as potentially dangerous, in that it could weaken their immunity against future interventions. For both reasons, we expect to find generalised resistance to the idea of precedent in Security Council decision-making.

Given the incentives to avoid both creating and referring to precedent, any evidence of such activity will offer strong support for our argument. Issues relating to sovereignty and the use of force within the territory of another state constitute hard cases for our theory of normative evolution. The evidence shows, however, that Security Council members, denying it all the while, create and consider precedent. The representative of Zimbabwe captured this paradox in his remarks during a discussion of the proposed intervention in Somalia: 'Any unique situation and the unique solution adopted create of necessity a precedent against which future, similar situations will be measured. ${ }^{38}$ We take the use of precedent as evidence of an emerging argumentation framework.

${ }^{38}$ United Nations Security Council, Provisional Verbatim Record of the Three Thousand One Hundred and Forty-Fifth Meeting, 3 December 1992, S/PV.3145, p. 7. 


\section{Rule contexts}

Sovereignty norms are the fundamental constitutive rules of international society. Two sovereignty-related rules erect a prima facie barrier to forcible humanitarian intervention. The first, a constitutive precept of international law, establishes exclusive internal jurisdiction. The second is the ban on the use of violence: no state may resort to force of arms in its interactions with other states. Non-intervention norms find expression in the UN Charter, especially in Article 2(7), which forbids the $\mathrm{UN}$ organisation (or, in the prevailing interpretation, its member states) 'to intervene in matters which are essentially within the domestic jurisdiction of any state'. The ban against intervention has been reinforced in 'soft law', through a series of General Assembly resolutions, including the 1950 Peace Through Deeds Resolution, the 1957 Declaration Concerning the Peaceful Coexistence of States, the Declaration on Inadmissibility of Intervention in Domestic Affairs of States and Protection of their Independence and Sovereignty (1965), and the Declaration on Principles of International Law Concerning Friendly Relations and Cooperation Among States in Accordance with the Charter of the United Nations (1970).

United Nations rules against the use of force also create a presumption against the legitimacy of armed humanitarian intervention. Article 2(4) enunciates the famous injunction against the use or threat of force. The Charter provides only two explicit exceptions to this prohibition. The first is 'individual or collective self-defence' (Art. 51), and the second is UN action, when mandated by the Security Council, to halt 'threats to the peace, breaches of the peace, and acts of aggression' (Chapter VII). Thus the Charter does not identify enforcement of human rights as one of the permissible justifications for the use of force. Legal scholars have nevertheless argued that forcible humanitarian intervention is clearly compatible with central objectives of the $\mathrm{UN}$ and that the absence of a prohibition makes it permissible. ${ }^{39}$

International human rights norms have undergone steady development since the Second World War; they also find expression in the United Nations Charter and in other UN conventions and declarations. The preamble to the Charter affirms a common 'faith in fundamental human rights, in the dignity and worth of the human person, in the equal

${ }^{39}$ Fernando R. Tesón, Humanitarian Intervention: An Inquiry into Law and Morality, 2nd edn (Irvington-on-Hudson, NY: Transnational Publishers, 1997). 
rights of men and women'. Article 1 of the Charter enumerates the purposes of the UN, which include the achievement of 'international cooperation ... in promoting and encouraging respect for human rights and for fundamental freedoms for all without distinction as to race, sex, language, or religion' (Article 1(3)). Article 55(c) declares that the United Nations 'shall promote ... universal respect for, and observance of, human rights and fundamental freedoms', and in the following article 'all Members pledge themselves to take joint and separate action in cooperation with the Organization for the achievement' of those purposes (Chapter IX, Article 56).

The members of the UN followed up with a series of declarations and conventions that spelled out a range of human rights, starting with the Convention on the Prevention and Punishment of the Crime of Genocide (1948), and the Universal Declaration of Human Rights (1948). In Jack Donnelly's account, ${ }^{40}$ formal rule-making culminated with the International Covenant on Economic, Social, and Cultural Rights and the International Covenant on Civil and Political Rights (both in 1966). Treaties on special topics followed, including women's rights (1979), torture (1984), and the rights of children (1989). Still, by the mid-1990s, though 'norms and the process of norm creation have been almost completely collectivized', and monitoring has moved somewhat in that direction, 'implementation and enforcement remain almost exclusively national' ${ }^{41}$ In short, though the UN Charter does not explicitly provide for collective enforcement of human rights, there were clearly grounds to argue that using force against massive abuses was consistent with the purposes of the institution.

\section{Disputes, discourse, precedent}

International sovereignty rules are fundamentally in tension with universal human rights norms. Rule conflicts are brought to the surface by actors who dispute the appropriate course of action in a specific circumstance. During the 1990s, a series of cases triggered Security Council debates on humanitarian intervention. Instances of humanitarian intervention did occur before 1990, but we focus on the post-1990 cases, for two reasons. First, in the pre-1990 cases, when the Security Council

\footnotetext{
${ }^{40}$ Jack Donnelly, 'State Sovereignty and International Intervention: The Case of Human Rights', in Gene M. Lyons and Michael Mastanduno (eds.), Beyond Westphalia? State Sovereignty and International Intervention (Baltimore: Johns Hopkins University Press, 1995), p. 123.

${ }^{41}$ Donnelly, 'State Sovereignty and International Intervention', p. 146.
} 
was involved, it was asked to condone or condemn interventions that had already been carried out unilaterally (for instance, by India in East Pakistan, France in Central Africa, Vietnam in Cambodia, and Tanzania in Uganda). ${ }^{42}$ In contrast, in the 1990s, the Security Council was asked to consider multilateral interventions under UN mandate before the fact. Even in controversial instances of multilateral intervention by groups of states without explicit Security Council authorisation (northern Iraq, Kosovo), the UN had already debated and taken specific actions in response to serious human rights concerns.

Second, the end of the Cold War and the collapse of the Soviet Union reconfigured the international political context. Prior to 1990, the superpowers would veto any proposed intervention out of Cold War politicostrategic concerns, thus excluding humanitarian intervention from multilateral decision-making in the UN. Since 1990, the Security Council has been able to debate and often reach consensus in cases that previously would have been deadlocked by the US-Soviet rivalry. In addition, the nature of interventions changed. Before 1990, interventions were generally unilateral; after that date, most interventions have been multilateral.

The Security Council is the primary forum in which states debate norms of humanitarian intervention. Though the speeches offered by delegates are usually carefully scripted and involve generous doses of posturing and pretence, the statements offered in Security Council meetings do expose the normative arguments that actors deploy in order to shape the rules. Participants understand that their statements become part of a larger discourse and a permanent record, and frame normative claims in an effort to shape that discourse, as well as the inevitable accumulation of precedent, in ways compatible with their perceived interests and values. We have examined the transcripts of Security Council debates on proposals for humanitarian intervention in nine cases: Liberia, Iraq (the safe havens), Bosnia, Somalia, Haiti, Rwanda, Sierra Leone, Kosovo, and East Timor. These cases include all of the post-1990 interventions in which humanitarian objectives were central. In two of them (Bosnia, Somalia), the Security Council authorised intervention by

\footnotetext{
42 These are the four cases commonly identified as instances of humanitarian intervention pre-1990, though scholars disagree as to which ones should count. Tesón, Humanitarian Intervention, includes Uganda, Central Africa, East Pakistan, and the US invasion of Grenada. Nicholas J. Wheeler, Saving Strangers: Humanitarian Intervention in International Society (Oxford: Oxford University Press, 2000), includes East Pakistan, Cambodia, and Uganda. Sean D. Murphy, Humanitarian Intervention: The United Nations in an Evolving World Order (Philadelphia: University of Pennsylvania Press, 1996), includes East Pakistan, Central Africa, and Uganda.
} 
UN ('blue helmet') forces. In six cases (Bosnia, Somalia, Haiti, Rwanda, Sierra Leone, East Timor), it authorised or expressed approval for (after the fact) armed interventions carried out by coalitions of member states ('multilateral forces'). In two cases (Iraq, Kosovo) member state coalitions conducted forcible humanitarian interventions without specific Security Council mandates but in the context of ongoing Security Council efforts to deal with major human rights disasters. ${ }^{43}$

It bears keeping in mind that there are powerful reasons not to expect the use of precedent in Security Council discussions. Indeed, we find explicit and implicit attempts to avoid the setting of precedent. Explicit efforts typically took the form of statements by national representatives to the effect that in authorising intervention, the Security Council was not establishing precedent for future cases. Implicit attempts to suppress the formation of precedent involved statements that emphasised the 'exceptional', 'singular', or 'unique' situation confronting the Security Council. By declaring that a given intervention is unique, states assert that from the particulars of an exceptional case one cannot derive general norms or principles. Such arguments are intended to foreclose the drawing of analogies from one case where intervention was permitted to a subsequent set of circumstances. No future case could ever match the 'singular' features of, say, Somalia. But of course no two cases ever match in all of their details; the question is whether actors construct analogies between a few salient features of two cases that are, by definition, unique. The answer is that they do, because argument by analogy and precedent is an inherent feature of normative reasoning.

We analysed the verbatim transcripts of twenty-two meetings of the Security Council in which the topic of discussion was intervention to halt or alleviate large-scale human rights abuses in nine countries. Meetings of the Security Council are debates only in a loose sense. That is,

43 This brief summary necessarily omits many of the nuances relevant to individual cases. For instance, we have included the case of Iraq even though the Security Council did not expressly authorise forcible intervention to create the 'no-fly zones'. In Resolution 688, the Council addressed major human rights abuses occurring within Iraq and ordered that country to allow unimpeded access by humanitarian relief organisations. In Liberia and Sierra Leone, the Security Council declined to consider authorising intervention by UN forces during the periods of most intense human rights violations, despite requests that it do so. Instead, the Security Council endorsed the intervention carried out by a multinational force sponsored by and composed of members of the Economic Community of West African States (ECOWAS); the intervention force bore the acronym ECOMOG (ECOWAS Monitoring Group). On Liberia, see David Wippman, 'Enforcing the Peace: ECOWAS and the Liberian Civil War', in Lori F. Damrosch (ed.), Enforcing Restraint: Collective Intervention in Internal Conflicts (New York: Council on Foreign Relations Press, 1993). 
members of the Council, and delegations that request to offer statements to it, do not engage in direct exchanges of arguments and counterarguments in order to win votes. Some delegates speak before the vote, and some speak after. The speeches are more like set pieces, as the members essentially know in advance what the outcome of the vote will be. Indeed, the serious debating and negotiating take place prior to the meetings, in bilateral conversations or in 'informal consultations' of the Security Council as a whole. Nevertheless, the official statements do reveal the normative stances adopted by the various states, as they seek to imprint their interpretations of the norms on the public record.

We found direct or indirect attempts to negate the precedential value of the decision being taken in six meetings, involving four cases (Iraq, Bosnia, Somalia, and Haiti). Indirect efforts include statements highlighting the uniqueness of the present case, so as to cut off analogies and diminish its potential significance as precedent. An example comes from the statement of the Spanish delegate during discussion of the resolution to authorise a multinational intervention force for Haiti: 'It must be stressed that this decision is an exceptional one, taken in response to the singular circumstances attending the Haitian crisis. ${ }^{\prime 4}$ Direct efforts include explicit disavowals that the current decision would create any precedent for future situations, like the following statement by the Indian delegate in the meeting authorising forcible intervention in Somalia: 'The present action should not, however, set a precedent for the future. ${ }^{45}$ A statement by China regarding Somalia incorporates both direct and indirect approaches: 'It is our understanding that this authorization is based on the needs of the unique situation in Somalia and should not constitute a precedent for United Nations peace-keeping operations. $^{46}$

More striking is the frequency with which speakers in the Security Council made positive references to precedent. Table 1 reports all thirty such references that we found in the twenty-two meetings. Of these, twenty-two drew analogies with earlier cases. Nineteen of these concerned previous Security Council decisions on humanitarian intervention; the other three references were to Nazi Germany (2) or South Africa. The remaining eight statements regarding precedent were

\footnotetext{
44 United Nations Security Council, Provisional Verbatim Record of the Three Thousand Four Hundred and Thirteenth Meeting, 31 July 1994, S/PV.3413, p. 19.

${ }^{45}$ United Nations Security Council, S/PV.3145, p. 51.

${ }^{46}$ United Nations Security Council, Provisional Verbatim Record of the Three Thousand One Hundred and Eighty-eighth Meeting, 26 March 1993, S/PV.3188, p. 22.
} 
Table 1 Uses of precedent in United Nations Security Council deliberations

\begin{tabular}{|c|c|c|c|c|}
\hline Date & $\begin{array}{l}\text { Agenda } \\
\text { topic }\end{array}$ & Precedent & $\begin{array}{l}\text { Speaker's } \\
\text { country }\end{array}$ & UN Doc. \\
\hline 5 April 1991 & Iraq & South Africa & United Kingdom & S/PV.2982:64-65 \\
\hline 13 Ảug 1992 & Bosnia & Somalia & Zimbabwe & S/PV.3106:18 \\
\hline 13 Aug 1992 & Bosnia & Nazi Germany & Austria & S/PV.3106:26 \\
\hline 19 Nov 1992 & Liberia & Somalia & Sierra Leone & S/PV.3138:56 \\
\hline 3 Dec 1992 & Somalia & Iraq, Bosnia & Austria & S/PV.3145:31 \\
\hline 3 Dec 1992 & Somalia & Future - Bosnia & Austria & S/PV.3145:32 \\
\hline 3 Dec 1992 & Somalia & Future & Hungary & S/PV.3145:48 \\
\hline 3 Dec 1992 & Somalia & Future & Zimbabwe & S/PV.3145:7 \\
\hline 31 Mar 1993 & Bosnia & Future & France & S/PV.3191:4 \\
\hline 4 June 1993 & Bosnia & Kuwait & Venezuela & S/PV.3228:25 \\
\hline 6 June 1993 & Somalia & Bosnia & Pakistan & S/PV.3229:7 \\
\hline 6 June 1993 & Somalia & $\begin{array}{l}\text { Future - Cambodia, } \\
\text { Yugoslavia }\end{array}$ & Venezuela & S/PV.3229:17 \\
\hline 6 June 1993 & Somalia & $\begin{array}{c}\text { Future - Bosnia, } \\
\text { Cambodia }\end{array}$ & Russia & S/PV.3229:22 \\
\hline 8 June 1994 & Rwanda & Nazi Germany & Czech Republic & S/PV.3388:3 \\
\hline 22 June 1994 & Rwanda & Somalia & New Zealand & S/PV.3392:7 \\
\hline 15 July 1994 & Haiti & $\begin{array}{l}\text { General past } \\
\text { practice and } \\
\text { principles }\end{array}$ & Sec. General & S/1994/828:5-6 \\
\hline 31 July 1994 & Haiti & Future & New Zealand & S/PV.3413:22 \\
\hline 26 Mar 1999 & Kosovo & Bosnia & Bosnia & S/PV.3989:14-15 \\
\hline 26 Mar 1999 & Kosovo & $\begin{array}{l}\text { General recent } \\
\text { precedents of } \\
\text { action by regional } \\
\text { organisations }\end{array}$ & Slovenia & S/PV.3989:3 \\
\hline 10 June 1999 & Kosovo & Cambodia & Netherlands & S/PV.4011:13 \\
\hline 10 June 1999 & Kosovo & Rwanda & Canada & S/PV.4011:13 \\
\hline 10 June 1999 & Kosovo & Bosnia & Malaysia & S/PV.4011:16 \\
\hline 10 June 1999 & Kosovo & Bosnia & Bahrain & S/PV.4011:19 \\
\hline 10 June 1999 & Kosovo & Croatia & Croatia & $\begin{array}{l}\text { S/PV.4011 } \\
\quad \text { (resumption):12 }\end{array}$ \\
\hline 10 June 1999 & Kosovo & $\begin{array}{l}\text { Slovenia, Croatia, } \\
\text { Bosnia }\end{array}$ & Albania & $\begin{array}{l}\text { S/PV.4011 } \\
\quad \text { (resumption): } 14\end{array}$ \\
\hline 11 Sept 1999 & E. Timor & $\begin{array}{c}\text { Somalia, Rwanda, } \\
\text { Bosnia, Kosovo }\end{array}$ & Italy & $\begin{array}{l}\text { S/PV. } 4043 \\
\text { (resumption): } 13\end{array}$ \\
\hline 11 Sept 1999 & E. Timor & Kosovo & Italy & $\begin{array}{l}\text { S/PV. } 4043 \\
\quad \text { (resumption): } 14\end{array}$ \\
\hline 11 Sept 1999 & E. Timor & Kosovo & Austria & $\begin{array}{l}\text { S/PV.4043 } \\
\quad \text { (resumption):27 }\end{array}$ \\
\hline 11 Sept 1999 & E. Timor & Future precedent & Singapore & $\begin{array}{l}\text { S/PV. } 4043 \\
\quad \text { (resumption): } 20\end{array}$ \\
\hline 25 Oct 1999 & E. Timor & $\begin{array}{l}\text { Rwanda, Somalia, } \\
\text { Haiti, Zaire }\end{array}$ & Canada & S/PV.4057:17 \\
\hline
\end{tabular}


prospective in nature, that is, they expressed a hope that the current case would establish precedent for other specific crises or for the future more generally. This is strong evidence that, even in settings where one might not expect it, actors regularly refer to analogies and precedents as they engage in collective normative reasoning.

In substantive terms, the resolutions approved in these meetings have clearly pushed the development of norms permitting forcible intervention to halt human rights violations. ${ }^{47}$ In Bosnia and Somalia, the Security Council created precedents for deploying armed force to assist in the delivery of emergency relief supplies. The Somalia case, in addition, broke new ground by authorising intervention in a crisis that did not pose any real threat to international peace and security. With the intervention in Haiti, the Security Council established that the UN could act to restore to power a democratically elected government. Its decisions on Haiti and East Timor, and its refusal to condemn the NATO bombing campaign on behalf of Kosovo, showed that the UN could authorise humanitarian intervention by multinational forces under national command. ${ }^{48}$

\section{Emergence of an argumentation framework}

In short, a rudimentary argumentation framework has evolved in the domain of forcible humanitarian intervention. It is now established that forcible intervention is permissible, though not required, when abuses of human rights are massive, that is, both grievous and numerous. No standard of grievousness exists, but in all of the cases considered here, the abuses included serious bodily violence (rape, torture, mutilation) and deaths. Other kinds of human rights violations (detention without filing charges, arbitrary arrest) do not justify forcible responses. Though there is no precise threshold for 'massive', it is clear that occasional

\footnotetext{
47 We are not arguing that the interventions did in fact effectively curtail human rights abuses. Indeed, the Security Council did not explicitly authorise intervention to assist the Kurds or the Kosovar Albanians, though in both cases it did not condemn the actions of multinational intervention forces. The Security Council essentially opted not to act on the horrendous human rights violations occurring in Liberia and Sierra Leone, and offered too little, too late to affect the genocide being carried out in Rwanda.

${ }^{48}$ The Security Council discussed in March 1999 a draft resolution proposed by Russia, Belarus, and India to condemn the NATO bombing campaign against Yugoslavia as a violation of international law and demand an immediate cessation. The resolution was defeated by twelve votes to three, only China, Namibia, and Russia voting in favour. Voting against the resolution were Argentina, Bahrain, Brazil, Canada, France, Gabon, Gambia, Malaysia, Netherlands, Slovenia, the United Kingdom, and the United States. A solid majority was therefore unwilling to condemn the intervention, though the point was vigorously contested by other states.
} 
human rights violations, even continuing over a period of years, will not invite armed intervention (other kinds of international response being available). Conversely, opponents of intervention in a specific case can argue that the abuses are not sufficiently widespread or serious to justify military action against the offending state.

The argumentation framework also makes the case for intervention stronger when a human rights crisis includes a transnational dimension, by fomenting armed conflict in neighbouring states, or even by creating large flows of people fleeing from danger or forcibly expelled from their homes. The counter-argument, of course, is that a particular crisis is entirely internal to a country, in which case non-intervention norms should apply (although the international community can provide assistance to refugees without intervening militarily). Even so, it is clear that many states regard governments engaged in massive human rights violations as having forfeited their sovereignty-based claims to immunity from outside intervention.

A blanket non-intervention argument based simply on sovereignty is clearly no longer valid. The cases decided in the 1990s will make it much less plausible for governments to argue, in response to future large-scale human rights violations in some part of the world, that international norms prohibit intervention. Other potential exclusions have also been weakened. 'Legal' intervention need not depend on a request or even agreement from the target state. UN-led forces (blue helmets) are not the only valid mode of intervention; the UN can also authorise groups of willing states or regional organisations to carry out interventions under national command.

Finally, the record of Security Council deliberations and decisions is not the only indicator that an argumentation framework has emerged. It is by now almost universally accepted among legal scholars that forcible intervention to halt massive human rights abuses can be permissible under international law. Indeed, among the publicists, the debate has already moved on to fleshing out more of the details - conditions, exceptions, qualifications - of the argumentation framework. ${ }^{49}$

49 The legal literature is too voluminous to cite comprehensively; representative works include Menno T. Kamminga, Inter-State Accountability for Violations of Human Rights (Philadelphia, PA: University of Pennsylvania Press, 1992); Laura W. Reed and Carl Kaysen, Emerging Norms of Justified Intervention (Cambridge, MA: American Academy of Arts and Sciences, 1993); Lori F. Damrosch, Enforcing Restraint: Collective Intervention in Internal Conflicts (New York: Council on Foreign Relations Press, 1995); Murphy, $\mathrm{Hu}$ manitarian Intervention; Oliver Ramsbotham and Tom Woodhouse, Humanitarian 


\section{Conclusion}

Two summary points deserve emphasis. First, we deny any inherent, theoretically significant, distinction between how international and domestic regimes operate. Put simply, the range of variation is as great within categories of domestic and international as between these categories, and mainstream international relations theory has woefully failed to distinguish, theoretically, one kind of rule system from another. ${ }^{50}$ Colombia, Sierra Leone, and Somalia are hardly states at all, in the Waltzian ${ }^{51}$ sense of being centralised; while in the international system there exist zones constituted by highly institutionalised modes of governance. Further, national politicians, interacting in domestic political contexts, can be more jealous of their prerogatives than statesmen negotiating with one another on the global stage; and supranational courts can be more effective on a day-to-day basis than many national jurisdictions.

Second, we would like this chapter to be read as an attempt to formalise some important insights of process-based approaches to law, ${ }^{52}$ and to give better micro-foundations to rule-oriented constructivism. ${ }^{53}$ Neorationalist perspectives (game theory and rational choice) on international regimes and legal systems have contributed to our understanding of why and how actors build new institutional arrangements to help them achieve joint purposes. But neorationalism, to the extent that it fails to provide a convincing account of why and how normative discourse and legal institutions develop a 'life of their own', has not been able to explain certain crucial dynamics of institutional change. ${ }^{54}$ Our differences with neorationalists do not reduce to an argument about the status of rationality. We assume that all actors are rational (in the sense of seeking to maximise their subjective utility given both cognitive and institutional limits), but take seriously the view that strategic

Intervention in Contemporary Conflict: A Reconceptualization (Cambridge: Polity Press, 1996); Tesón, Humanitarian Intervention; and Wheeler, Saving Strangers.

${ }^{50}$ Friedrich V. Kratochwil, Rules, Norms, and Decisions: On the Conditions of Practical and Legal Reasoning in International Relations and Domestic Affairs (Cambridge: Cambridge University Press, 1989); and Stone, 'What is a Supranational Constitution?'

51 Kenneth N. Waltz, Theory of International Politics (New York: Random House, 1979).

52 For example, H. H. Koh, 'The 1998 Frankel Lecture: Bringing International Law Home', Houston Law Review 35: 3 (1998).

${ }^{53}$ For example, Nicholas Onuf, 'The Constitution of International Society', European Journal of International Law 5: 1 (1994).

${ }^{54}$ See the exchange between Vanberg, 'Reply to Stone Sweet', and Stone Sweet, 'Rules, Dispute Resolution, and Strategic Behavior'. 
action is heavily conditioned by existing institutional arrangements and normative uncertainty.

A more generic issue raised here is whether theoretical primacy should be assigned, a priori, to normative-ideational rather than material-physical power. At times, these two types of influence (or types of resources for action), may be in opposition to one another, as when one excludes the use of the other. More often, they are interlinked, with their relative importance varying according to the social context. In triadic settings, formal dispute resolution procedures and bodies of precedent substantially mediate the effects of material power resources. Indeed, some systems of triadic dispute resolution may explicitly seek to dilute, if not eliminate, the effects of material disparities, by forcing parties to engage in normative suasion within structures of precedent and argumentation. In dyadic contexts, material power is presumptively less mediated, but may nonetheless be shaped and constrained by normative structures.

If powerful states dictate international rules and change them as they please, then we need only focus on material power relations and the analysis need go no further. To be sure, powerful countries often exercise the greatest influence on the rules of international society. Indeed, we take it as axiomatic that in any social system, institutions, 'or at least the formal rules, are created to serve the interests of those with the bargaining power to devise new rules' ${ }^{55}$ Powerful actors (rich countries, large transnational companies) can offer payoffs to those who agree to their preferred rules, and they can inflict costs on those who refuse. More subtly, but perhaps more pervasively, powerful actors shape the broader intellectual and cultural environment within which other actors make their way. It is not necessarily the case that leading states actively manipulate ideas and culture for their own benefit; the point is closer to the Gramscian one that simply by virtue of their size and reach, leading states produce much of the scientific, legal, and cultural environment within which other actors live.

Still, the emergence and evolution of international norms can have an impact even on powerful states through various mechanisms. We have focused on mechanisms associated with norm-based conflict and organised dispute resolution in this chapter, but of course there are others. The development of international rule structures (like rights), for example, can offer transnational actors, and a state's own subjects, new

${ }^{55}$ North, Institutions, p. 16. 
possibilities for pursuing their political interests. Much of the action in modern international law concerns how international norms are noticed, absorbed, and used politically within the legal frameworks of states. Citizens, groups, firms, non-governmental organisations, and governmental officials may then be led to alter their own cognitive schema, values, and decision-making in light of such processes. This dynamic deserves more attention in light of the themes raised by this volume, ${ }^{56}$ and in light of the constructivist claim that international norms are basic to how states' values, objectives, and identity are constructed and evolve over time. ${ }^{57}$

${ }^{56}$ But see Koh, 'The 1998 Frankel Lecture'; Andrew P. Cortell and James W. Davis, Jr, 'How Do International Institutions Matter? The Domestic Impact of International Rules and Norms', International Studies Quarterly 40: 4 (1996); and Andrew P. Cortell and James W. Davis, Jr, 'Understanding the Domestic Impact of International Norms: A Research Agenda', International Studies Review 2: 1 (2000).

${ }_{57}$ Nicholas Onuf, World of Our Making: Rules and Rule in Social Theory and International Relations (Columbia: University of South Carolina Press, 1989); and Alexander Wendt, Social Theory of International Politics (Cambridge: Cambridge University Press, 1999). 